Teresa Maria Włosowicz

Wyższa Szkoła Ekonomiczno-Humanistyczna w Bielsku-Białej https://orcid.org/0000-0001-8767-9332 melomane.plurilingue@gmail.com

\title{
Teaching and learning French as a third or additional language in an international context: selected aspects of language awareness and assessment
}

\begin{abstract}
The article investigates the teaching of French as a third or additional language (De Angelis, 2007) at the beginning level to international students from different language backgrounds and their learning of that language, as perceived by the students themselves, as well as revealed by tests. Special attention is paid to the areas of difficulty perceived by the students, their perception of the similarities and differences between French and their native languages as well as between French and other languages they already know, especially English, and of the teaching strategies, which included cross-linguistic awareness-raising. Assessment of their progress in French is also considered. The study involves a combination of two methods: long-term classroom observation and assessment of 29 students, and a questionnaire filled out by 20 of those students. As the results show, the participants' awareness of similarities and differences is fairly high, but their attitudes towards awareness-raising, feedback, etc. vary considerably. The tests are both formative and summative (but also providing feedback). However, the feedback was mutual: apart from giving feedback to the students, the author could also modify her teaching according to their problems and wishes concerning the French classes.
\end{abstract}

Keywords: language awareness, assessment, feedback, French as a third or additional language

Słowa kluczowe: świadomość językowa, ocenianie, informacja zwrotna, język francuski jako język trzeci lub kolejny 


\section{Introduction}

The aim of the study is an investigation of teaching French as a third or additional language (De Angelis, 2007) to international students who have different linguistic repertoires, the assessment of their learning outcomes, and their perception of the French language in the light of their language awareness. What is broadly defined here as the students' perception of the French language includes areas of difficulty, as well as the similarities and differences between French and other languages known to them. Also taken into consideration is their perception of the French language course, including awareness-raising, the teacher's assessment of their progress in French, and their attitudes towards assessment in general. As teaching and learning are inextricably connected, the acquisition of French is analysed both from the teacher's and the students' points of view. Moreover, while the teacher's assessment is accompanied by a considerable amount of feedback, the students' comments and expectations are also taken into account as feedback for the teacher, so the feedback is largely mutual.

What is particularly important is that the participants are all at least bilingual, so they can be assumed to have a higher level of language awareness than monolinguals learning a second language (Hufeisen, 2018; Jessner, 1999; Klein, 1995). In accordance with Hufeisen's (2018) Factor Model, it can be supposed that they have already developed strategies specific to the learning of foreign languages and, at the same time, they know more languages, which can serve as potential sources of transfer. This is especially important in the case of students whose native languages are more distant from French (for example, Azerbaijani, Albanian or Georgian), but whose knowledge of English can serve both as a source of language transfer and a point of reference. The language of instruction is English, as the learners are not advanced enough to understand explanations in French. However, it cannot be taken for granted that they can apply their language awareness to the learning of French. Yet another problem in teaching and evaluating multilinguals is the fact that the presence of several languages in their linguistic repertoires leads to cross-linguistic interaction (Herdina and Jessner's (2002: 29) term used to cover transfer, interference, etc.) and, as a result, assessment based on monolingual norms might be unfair (Gorter, Cenoz, 2017).

However, while the criteria of assessment for research purposes may, for example, accept non-target forms as being communicatively effective, official course assessment often has to show if the goals set in the syllabus have been met. Thus, one might have a dilemma whether to assess one's students' language production, taking into consideration their multilingual repertoires, 
or to give them grades based on the target structures they are supposed to master. On the basis of the results, we will attempt to suggest an answer to the problem of assessing multilingual students' French (or, more generally, a third or additional language) in an international context.

The assessment of the participants' French language skills in this study is based on formative tests conducted during the semester and summative tests at the end of it (Bachman, 2014), as well as on the observation of their participation in classroom activities. In addition to this, their language awareness and attitudes are investigated by means of a questionnaire. Even though the responses to the questionnaire are inevitably subjective and certain inconsistencies may be due to the students' individual perception or expectations, the responses can be assumed to reveal important information about the students' individual processes of learning French.

\section{Assessment as a component of foreign language teaching}

Teaching generally involves some assessment. This can be divided into formative assessment, which 'takes place during instruction and learning and is intended to provide feedback for the improvement of both' (Bachman, 2014: 8), and summative assessment, which 'typically takes place at the end of instruction and learning and is intended to provide feedback for making decisions about advancement, progress or certification' (Bachman, 2014: 8). However, the distinction between these types of assessment is not clear-cut, as the same data can serve the purposes of either formative or summative assessment (Rea-Dickins, 2007: 509). According to Black (1998: 35, as cited in Rea-Dickins, 2007: 509), '[t]he formative and summative labels describe two ends of a spectrum in school-based assessment rather than two isolated and completely different functions.' Still, the practical purposes of testing are of particular importance. As Bachman (2014: 14) concludes, the main challenges to language testers are related to contexts in the real world where test results are the basis for decisions about learners and institutions.

Another division of assessment is based on two modes: the implicit mode, which is continuous, integrated with teaching and 'the teacher and the students are essentially unaware that assessment is taking place' (Bachman, 2014: 8), and the explicit mode, which is distinct from teaching and is perceived by both the teacher and the students as assessment (Bachman, 2014: 9). According to Bachman and Palmer (2010: 29, as cited in Bachman, 2014: 9), both forms of assessment can serve formative and summative purposes, for example, implicit observation of a student's participation in classes can influence the teacher's decision about the final grade, or the results of an explicit test can prompt the teacher to focus on a specific area. 
Consequently, both modes of classroom-based assessment (Hill, McNamara, 2012: 396) are necessary and can be regarded as complementary. Obviously, assessment is not limited to tests and examinations, which is why Rea-Dickins (2001, as cited in Hill, McNamara, 2012: 396) has proposed the notion of 'assessment opportunity', which includes a wide range of assessment activities. Some of these are unplanned and intuitive and may sometimes not be considered assessment, but according to Hill and McNamara (2012: 397), they should be included in the definition of an assessment opportunity, which covers:

any actions, interactions or artifacts (planned or unplanned, deliberate or unconscious, explicit or embedded) which have the potential to provide information on the qualities of a learner's (or group of learners') performance.

In other words, the processes of language teaching and learning provide a number of assessment opportunities, which can be exploited by both the teacher and the students to analyse the current situation and achieve better results. Apart from test results, feedback can involve comments on particular tasks and utterances, as well as on homework (Edelenbos, Kubanek-German, 2004: 279-280).

A teacher should thus develop 'diagnostic competence' or 'the ability to interpret students' foreign language growth, to skilfully deal with assessment material and to provide students with appropriate help in response to this diagnosis' (Edelenbos, Kubanek-German, 2004: 260). It should include openness, a reflective approach to teaching, the ability to select and adapt various assessment instruments, to correct one's own expectations, as well as to promote learning by developing learner autonomy, language awareness and self-assertiveness (Edelenbos, Kubanek-German, 2004: 277-279). Following Bransford et al. (2000), Edelenbos and Kubanek-German (2004: 279) remark that a teacher should be able to call on his or her students' earlier knowledge and integrate it into current teaching, which allows him or her to ask the right questions and give appropriate feedback.

However, in multilingual contexts assessment is particularly complex, as the students' earlier knowledge includes other languages than the language of instruction and the target language, also languages which are unknown to the teacher and/or to other learners. This begs the question of how to evaluate learners' performance which includes code-switching, borrowing or transfer from their native languages, especially negative transfer. The traditional approach to language teaching has kept languages separate (Gorter, Cenoz, 2017: 235). As a result, language assessment has focused on testing the knowledge of isolated languages. As Gorter and Cenoz (2017: 236) remark: 
Languages are evaluated separately and language proficiency is usually compared to that of a monolingual native speaker without taking into account the student's knowledge of other languages and penalizing the influence and use of other languages.

However, according to Cenoz and Gorter (2011, 2015, as cited in Cenoz, Gorter, 2017: 238), activating all of learners' linguistic resources makes learning more efficient than in the case of learning each language separately. A consequence of multilingual learning might be assumed to be multilingual assessment. According to Shohamy (2011: 427, as cited in Gorter, Cenoz, 2017: 243), mixing languages allows multilinguals to express themselves more effectively, which is why language assessment should use multilingual tasks. In a similar vein, Gorter and Cenoz (2017: 245) remark that traditional approaches 'might have been useful when school populations were more homogeneous' and conclude that now, in the globalised world, they should be replaced by holistic approaches.

Arguably, the question of how to implement such approaches remains largely unsolved. First, some standards of language proficiency should not be abolished, especially in the case of students studying foreign languages for professional purposes, such as future teachers and translators. As the present author suggested elsewhere (Włosowicz, 2017), a functional approach to language testing might be a solution, taking into consideration the purpose of studying the language, for example, obtaining a certificate. Supposing a Polish teacher of English taught his or her pupils to mix Polish with English indiscriminately, they would not be able to communicate properly in an English-speaking country. However, at lower levels of proficiency, explanations in the native language and even L1-based communication strategies are acceptable. Second, multilingual teaching does not have to result in language mixing as such, but rather in establishing associations between the different languages and building a multilingual repertoire (cf. Müller-Lancé, 2003). Therefore, raising awareness of the similarities and differences between the languages can make the students learn the target language more consciously, use learning strategies and, as a result, facilitate language learning, which the present author applies in her teaching of French to international students.

\section{Language awareness in multilinguals}

Learning several languages results in the acquisition of not only language competence and skills, but also of language learning experience, learning strategies and increased language awareness. Hufeisen's Factor Model 2.1 (Hufeisen, 2018) illustrates the factors that influence the acquisition of each 
subsequent language. The greatest qualitative difference is the one between L2 and L3 learning, as in the case of L3 some foreign language specific factors are already in place, such as '[i]ndividual foreign language learning experiences and strategies (ability to compare, transfer, and make interlingual connections), previous language interlanguages, interlanguage of target language(s),...' (Hufeisen, 2018: 186). In L4 learning, the only additional factor is the $\mathbf{L} 4$ interlanguage and language-specific factors related to it.

Language awareness is defined as 'explicit knowledge about language and conscious perception and sensitivity in language learning, language teaching and language use' (Garrett, James, 2000: 330, as cited in Byram, 2012: 6). On the other hand, James (1996: 139-140) defines language awareness as 'the possession of metacognitions about language in general, some bit of language, or a particular language over which one already has skilled control and a coherent set of intuitions.' By contrast, in James's view (1996: 141), consciousness of language relates to what learners do not know yet and what they have to learn. Following Rutherford and Sharwood Smith's definition of consciousness raising (1985: 274, as cited in James, 1996: 141) as 'the deliberate attempt to draw the learner's attention specifically to the formal properties of the target language', James (1996: 141) describes consciousness raising as 'an activity that develops the ability to locate and identify the discrepancy between one's present state of knowledge and a goal state of knowledge.'

Hence, one must be conscious of what still needs to be learnt and aware of the target language forms. To become available for intake, a piece of input must be noticed by the learner. Moreover, according to Widdowson (1992: 107, as cited in James, 1996: 145), introducing a metacognitive dimension into language pedagogy would involve comparisons between the native and the foreign language. Still, apart from differences, learners should be made aware of similarities. As Jessner (1999: 207) concludes, 'metalinguistic awareness can be increased through teaching similarities between languages.' By focusing on similarities, one can activate learners' prior knowledge and facilitate the acquisition of a further language.

It can be assumed that awareness and consciousness-raising activities should be part of foreign language teaching. Students should be given feedback so as to become conscious of what language areas they should work on (e.g. grammar, pronunciation, etc.), and, at the same time, they should be made aware of the similarities and differences between the target language and the languages they already know. This approach is also adopted by the present author in her French language course, and it includes such teaching strategies as drawing the students' attention to similarities and differences between French and the languages known to them, such as Spanish, as well 
as encouraging the discussion of possible similarities between French and languages known to the students but not to the teacher, such as Georgian.

As Bialystok (1985: 259-260) observes, teaching strategies have an effect on learning and a disparity between teaching strategies and learners' skills and strategies may reduce the benefits of instruction. For example, if a drill aiming at automating the use of a grammar structure goes beyond the learners' knowledge of the forms in question, such a strategy will fail. Another possible cause of failure is that the students are 'ideologically, pragmatically, or motivationally opposed to the strategy' (Bialystok, 1985: 260). Therefore, there should be at least minimal congruity between teaching and learning strategies. In fact, adult learners seem to know their learning needs and preferences (Wesche, 1981, as cited in Bialystok, 1985: 260) and may expect to be taught by the methods they are accustomed to (Włosowicz, 2016: 277).

Therefore, in order to find out whether the present author's teaching and assessing strategies were compatible with the international students' expectations and, in case of a disparity, to enable her to negotiate a solution, the students were given a questionnaire. As multilingual learners often have increased language awareness, it could be assumed that the awareness-raising and feedback would be appreciated by them, but it must be remembered that higher language awareness cannot be taken for granted either (Włosowicz, 2009).

\section{The study}

\subsection{Participants}

The overall study, including French language tests and classroom observation, was carried out during a French course for international students at WSB University in Dąbrowa Górnicza, with 29 participants whose native languages included: Spanish (9 participants), Azerbaijani (5), Georgian (4), Polish (3), Ukrainian (2), Albanian (1), Portuguese (1), Uzbek (1), Turkmen (1), Kazakh (1) and Lao (1). They are all advanced in English. Most of the students from the former Soviet republics know Russian, and the students' language repertoires also include other languages, such as German, Italian, Spanish, Turkish, or even Thai (the student from Laos).

They are all beginners in French, except one Polish and one Azerbaijani student who are at an intermediate level, but as there is no choice between different proficiency levels, they have to attend classes with the beginners, revise what they already know and learn some new things. The author takes a personalized approach to them and gives them extra materials, written home assignments and individual conversations during office hours. The only 
difference between the groups is that two groups (17 students) study French as their main foreign language and have 60 hours of French per semester and one group (12 students) takes French as their second foreign language (30 hours per semester), the main language being German, Spanish or Polish. This is why they took different tests, as the sixty-hour group had covered more material than the thirty-hour group.

It was, however, assumed that, as multilingual learners, they had comparable language awareness and could therefore complete the same questionnaire. The questionnaire was conducted with 20 participants, as nine students could not take part in it (for example, they were busy arranging formalities for an Erasmus scholarship.). Their native languages were: Spanish (5 participants), Azerbaijani (5), Polish (3), Ukrainian (2), Georgian (1), Turkmen (1), Kazakh (1), Albanian (1) and Lao (1).

\subsection{Method}

As mentioned above, the study combines two methods, using different assessment opportunities. On the one hand, the students took tests during and at the end of the semester. The author observed their performance and gave them feedback. This was not just a case of marking the responses as correct or incorrect, the target answers were written in the event when a student provided an incorrect answer or left a gap, so that they could learn something from the feedback too.

As spoken feedback during the classes was not recorded, it will be only mentioned as qualitative observations, but the test results have been analysed by means of chi-square tests comparing the number of correct, partly correct, and incorrect responses as well as 'avoidance' (an umbrella term for all gaps, including deliberate avoidance, or failure to retrieve the answer, etc.) for the different language groups for each task type: 1) vocabulary/semantics, 2) prepositions, 3) adjective endings, 4) error correction (correcting errors in sentences, based on the assumption that recognition is easier than production), and 5) a multiple-choice task.

As regards the criteria of correctness, the category of correct answers includes answers which are both semantically and formally (grammatically and orthographically) correct, for example: 'poivrons', in: 'je voudrais deux $\mathrm{p}$ verts, un oignon et trois tomates' (I would like two red peppers, an onion and three tomatoes), or 'payez', in 'Vous $\mathrm{p}$ comment?' (How are you going to pay?). Examples of partly correct answers include: 'Vous vous connaisse?' (target: Vous vous connaissez? - Do you know each other?), 'Vous payer comment?', where the correct verb occurs in an incorrect form, or in 
the case of nouns, 'deux poivron verts' (the singular instead of the plural). Partly correct prepositions include spelling mistakes which show that the student knew which preposition to use (e.g. ' $a$ ' instead of 'à'). By contrast, incorrect responses are either semantically incorrect (e.g. 'chez le market de fruits et légumes', for: chez le marchand de fruits et légumes (at the greengrocer's); in fact, this is a case of interference from English, as the French word for a market is 'marché'), grammatically incorrect (e.g. 'au Russie' instead of 'en Russie'), or both, as in: 'Vous voules quoi?' (target: 'Vous désirez?' - What would you like?). Here, the verb form is incorrect and, at the same time, the sentence would be quite impolite in the context.

In the case of error correction, a correct answer involved finding and correcting the error. A partly correct one involved finding the error but providing a non-target correction (e.g. j'ai besoin de légumes crus pour ma salade de fruits - I need raw vegetables for my fruit salad, where raw vegetables may fit in the context better than salmon). An incorrect answer involved either changing another part of the sentence, or providing a contextually incompatible 'correction' of the error (e.g. 'je voudrais une plaquette d'oranges' (I would like a bar of oranges), corrected to: 'un paquet' (a packet [of oranges]). Avoidance meant not correcting anything in the sentence. In fact, the criteria of analysis used in this article largely overlap with those applied to the students' performance on tests, as a correct answer corresponds to one point in a test, a partly correct answer corresponds to half a point, and for an incorrect answer or avoidance, they received zero points.

The first task type was broadly defined as vocabulary/semantics, as it involved filling in gaps with the appropriate words, but some grammatical information was also required in the case of verbs, yet the focus was on meaning (the appropriate lexical items in the context) and, if a verb form was incorrect, the answer was classified as 'partly correct'. However, it was not a typically grammatical task, such as putting verbs in the right forms. The words could also occur in a dialogue, not only in separate sentences. Examples of test items are included in Appendix 1 at the end of the article.

The preposition task involved completing sentences with the right prepositions, e.g. Le chien est la table. Inserting some prepositions was also required in the vocabulary/semantics tasks (e.g. Marina habite Moscou, Russie) and then the results were calculated together with those of the preposition task and not with the lexical words in the vocabulary/semantics task. The adjective ending task was related to the spelling of nationality adjectives according to their gender (e.g. 'Walter est autrichie . Inge n'est pas autrichie elle est alleman_') and it was done only by the thirty-hour group. There were two error correction tasks (a few items are presented in 
Appendix 1), which were done only in the sixty-hour group and their results are calculated together. Finally, the sixty-hour group did a multiple-choice task which covered different vocabulary and structures (for example, the partitive pronoun 'en') part of which is presented in Appendix 1.

Since no French textbook currently available includes all the elements in the right proportions (e.g. one or two exercises devoted to a new grammar structure can make students aware of its existence, but, arguably, they are not enough for them to learn the structure, or the topic of shopping covers books, multimedia and food in one handbook, and clothes in another), the course combines several textbooks instead of one. The main textbooks used in the course are AlterEgo+, A1, by Catherine Hugot et al. (2012), as well as Grammaire progressive du français. Niveau débutant, by Maïa Grégoire, with the participation of Gracia Merlo (2010), and Le Nouveau Taxi ! A1, by Guy Capelle and Robert Menand (2009). As is usually done at the beginning level, the course includes such topics as presenting oneself, countries and nationalities, food, shopping, describing people and places (including prepositions), and basic grammar structures, such as the present tense of verbs.

The language groups are as follows: Slavic (Polish and Ukrainian), Romance (Spanish and Portuguese), Turkic (Azerbaijani, Turkmen, Kazakh and Uzbek), Georgian (a Kartvelian language, not related to the other language groups (Velupillai, 2012: 78)), and 'other', as Albanian and Lao were put together as languages unrelated to any other language here and represented by single speakers (if a task was performed only by the sixty-hour group, the Albanian speaker's responses are taken into account; if a task was done only by the thirtyhour group, the Lao speaker's responses are analysed). Certainly, Albanian and Lao are not related to each other, but they are not related to French either, so they could be assumed to be languages distant from French. However, it must be remembered that, as they all knew English, even the speakers of more distant languages had some experience of a language sharing some similarities with French, including a number of cognates (Albanian is actually also Indo-European, but it belongs to a separate branch (Velupillai, 2012: 426)).

The questionnaire concerned the students' language repertoires and their perception of the classes, especially the cross-linguistic awareness-raising, as well as their attitudes towards assessment. The questionnaire is presented in Appendix 2 at the end of the article.

The research questions were: First, are there any differences in the students' performance in French depending on their native languages? Second, what, in their opinion, poses them particular difficulty? Third, to what extent do they notice similarities and differences between French and their native languages and other languages they know, and do they perceive them as a source of 
Teaching and learning French as a third or additional language in an international...

facilitation or an obstacle? Fourth, what are their attitudes towards the French classes, (especially the awareness-raising), assessment and feedback?

\subsection{Results}

First of all, the qualitative results of informal classroom observation reveal the following problems: French pronunciation is difficult for the students regardless of their native language. Apart from sounds which are specific to French, such as / $\mathrm{R} /$, they often confuse $/ \mathrm{y} /$, as in 'étudiant' (student) and / $\mathrm{l} /$, as in 'Louvre', and they tend to pronounce the mute ' $\mathrm{e}$ ' at the end of words, for example,

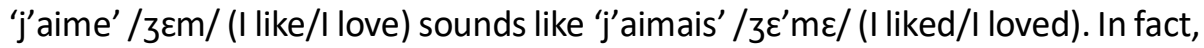
even though, as a Romance language, Spanish is generally related to French, the influence of Spanish on the L1 Spanish speakers' pronunciation is particularly visible, for example, 'ch' $/ \mathrm{J} /$, as in 'marchand' (merchant/vendor), tends to be pronounced as $/ \mathrm{t} / \mathrm{l}$, as in Spanish (though the influence of English cannot be excluded either). They also sometimes confuse $/ \mathrm{v} /$ and $/ \mathrm{b} /$. Thus, the perception of overall similarity between languages may lead to errors in areas where differences exist. Another problem might be some degree of speaking anxiety, but, as they are still beginners, it may be assumed that they do not yet feel ready to speak, so they should be given more time and practice.

As for the results of the French language tests, the correctness of the responses differs significantly for some tasks, but not for others. The contingency table for the vocabulary/semantics tasks is shown below (for both groups, as the vocabulary had been studied in class and the difficulty levels were comparable). (The numbers of responses are higher in some groups than the number of students might indicate, as the results of students who failed a test were calculated twice: those of the failed test and those of the retake; the problems were mostly revealed by the failed test, though the retake was not always fully correct either.)

\begin{tabular}{|l|r|r|r|r|r|}
\hline Native language & Correct & Partly correct & Incorrect & Avoidance & Total \\
\hline Slavic & 132 & 16 & 14 & 1 & 163 \\
\hline Romance & 235 & 49 & 28 & 8 & 320 \\
\hline Turkic & 175 & 30 & 18 & 21 & 244 \\
\hline Georgian & 89 & 15 & 18 & 7 & 129 \\
\hline Other & 41 & 6 & 2 & 2 & 51 \\
\hline
\end{tabular}

Table 1: The contingency table for the vocabulary/semantics tasks.

The difference between the groups is statistically significant at $p=0.0036(\mathrm{df}=$ 12). Though most answers are correct, the numbers of partly correct and incorrect answers are particularly high in the Romance group (10 students), 
while the avoidance rate is the highest in the Turkic group (8 students), and also in the Georgian one (4 students). While a long distance between languages makes learning difficult, a shorter distance and thus interference also lead to errors.

The next chi-square test was carried out for the error correction tasks. As they were done in the sixty-hour group, in the 'other' language group there is only the Albanian native speaker. The Slavic group only contained native speakers of Polish, and the Turkic group - only Azerbaijani speakers. The contingency table is presented as Table 2 below.

\begin{tabular}{|l|r|r|r|r|r|}
\hline Native language & Correct & Partly correct & Incorrect & Avoidance & Total \\
\hline Polish & 32 & 2 & 7 & 1 & 42 \\
\hline Romance & 80 & 2 & 23 & 7 & 112 \\
\hline Azerbaijani & 56 & 4 & 16 & 8 & 84 \\
\hline Georgian & 37 & 4 & 8 & 7 & 56 \\
\hline Albanian & 13 & 0 & 2 & 1 & 16 \\
\hline
\end{tabular}

Table 2: The contingency table for the error correction tasks.

The difference between the groups is not statistically significant at $p=0.65$, $\mathrm{df}=12$. This indicates that the students' ability to find and correct errors did not depend on their native language, but rather on how well they had learnt the vocabulary and structures.

The students' ability to use the right prepositions in sentence contexts was also compared by means of a chi-square test. The contingency table is presented as Table 3 below.

\begin{tabular}{|l|r|r|r|r|}
\hline Native language & Correct & Partly correct & Incorrect & Total \\
\hline Slavic & 22 & 4 & 7 & 33 \\
\hline Romance & 60 & 10 & 16 & 86 \\
\hline Turkic & 36 & 9 & 5 & 50 \\
\hline Georgian & 27 & 1 & 6 & 34 \\
\hline Other & 9 & 2 & 1 & 12 \\
\hline
\end{tabular}

Table 3: The contingency table for the preposition tasks.

Again the difference is not statistically significant at $p=0.5391, \mathrm{df}=8$, so it can be concluded that the use of prepositions did not depend on the students' native language, though the Romance language speakers made a larger number of errors than the other language groups. The Spanish speakers had problems with the French equivalents of the Spanish preposition 'en' ('in', but in some contexts also 'on'), which can have different equivalents in French, such 
Teaching and learning French as a third or additional language in an international...

as 'dans' (dans l'avion - in/on the plane), 'en' (en Russie - in Russia), 'à' (à Paris - in Paris), or 'au' (with masculine names of countries, e.g. au Japon - in Japan) and made such errors as '*dans Russie', '*dans Danemark', '*dans Hambourg', or '*en Danemark', though the form '*dans Hambourg' was also produced by two of the Georgian students.

The ability to use the right adjective endings was tested by a separate task only in the thirty-hour group, so the 'other' group only includes the native speaker of Lao. Similarly, as the only Portuguese speaker was in the sixty-hour group, all the Romance language speakers have Spanish as their L1. The results are presented in the contingency table below.

\begin{tabular}{|l|r|r|r|r|}
\hline Native language & Correct & Partly correct & Incorrect & Total \\
\hline Slavic & 30 & 5 & 5 & 40 \\
\hline Spanish & 38 & 1 & 1 & 40 \\
\hline Turkic & 36 & 2 & 2 & 40 \\
\hline Lao & 10 & 0 & 0 & 10 \\
\hline
\end{tabular}

Table 4: The contingency table for the adjective task

The results are not statistically significant at $p=0.1449, \mathrm{df}=6$. In general, the adjective endings were mastered fairly well by all the students, regardless of their native language.

Finally, the results of the multiple-choice test were calculated by means of a chi-square test. This task had been performed only by the sixty-hour group. The results are presented in the contingency table below.

\begin{tabular}{|l|r|r|r|}
\hline Native language & Correct & Incorrect & Total \\
\hline Polish & 18 & 2 & 20 \\
\hline Romance & 65 & 5 & 70 \\
\hline Azerbaijani & 39 & 1 & 40 \\
\hline Georgian & 28 & 12 & 40 \\
\hline Albanian & 8 & 2 & 10 \\
\hline
\end{tabular}

Table 5: The contingency table for the multiple-choice task.

The difference between the language groups is statistically significant at $p=$ 0.0014 , df $=4$. It appears that the Azerbaijani speakers performed the best and the Georgian ones the least well, but, in the light of the results of the other tasks, it cannot be assumed that the multiple-choice test was more difficult for Georgian speakers because of the language distance. Rather, it was a matter of absence from classes, incorrect guessing, etc. 
The areas the students perceived as of difficulty in French taken from the questionnaire, are presented in Table 6 below.

\begin{tabular}{|l|r|r|r|r|r|r|r|r|r|r|}
\hline $\begin{array}{l}\text { Native } \\
\text { language }\end{array}$ & Grammar & Vocabulary & Spelling & $\begin{array}{r}\text { Pronun- } \\
\text { ciation }\end{array}$ & $\begin{array}{r}\text { Speak- } \\
\text { ing }\end{array}$ & Writing & $\begin{array}{r}\text { Reading } \\
\text { comp. }\end{array}$ & $\begin{array}{r}\text { Listening } \\
\text { comp. }\end{array}$ & Other & Total \\
\hline Slavic & 2 & 0 & 3 & 5 & 0 & 1 & 0 & 1 & 0 & 12 \\
\hline Romance & 0 & 1 & 2 & 3 & 0 & 4 & 0 & 1 & 0 & 11 \\
\hline Turkic & 4 & 2 & 5 & 3 & 4 & 2 & 2 & 4 & 1 & 27 \\
\hline Georgian & 1 & 0 & 0 & 0 & 0 & 0 & 0 & 1 & 0 & 2 \\
\hline Albanian & 1 & 0 & 0 & 0 & 0 & 1 & 0 & 1 & 0 & 3 \\
\hline Lao & 1 & 0 & 1 & 1 & 1 & 0 & 0 & 0 & 0 & 4 \\
\hline
\end{tabular}

Table 6: The areas of difficulty perceived by the participants (contingency table).

Quite predictably, pronunciation, spelling, writing and listening comprehension are among the language areas perceived as most difficult. Grapheme-phoneme mapping in French is quite complex, which is why learning to spell and to write it is difficult. As mentioned above, the students have problems with French pronunciation. Grammar is also regarded as difficult, though the differences are quite visible: while it is difficult for speakers of languages more distant from French, it is not perceived as difficult by the Spanish speakers, who can rely on a number of similarities. The chi-square test comparing the language groups did not reveal a statistically significant difference, $(p=0.0169, \mathrm{df}=40)$. It may be concluded that, except for the Spanish speakers, the other students perceive more or less the same structures and skills as difficult.

The students were also asked how difficult they found French in general. They were asked to mark their responses on a five-point Likert scale (1 - very easy, 5 - very difficult). In fact, they do not perceive French as particularly difficult, as the mean is 3.39 , and their responses did not vary greatly ( $S D=0.85$ ). The students' responses concerning the similarity of their language and French are presented in the contingency table below:

\begin{tabular}{|l|r|r|r|r|r|r|r|r|r|}
\hline $\begin{array}{l}\text { Native } \\
\text { language }\end{array}$ & $\begin{array}{r}\text { Vocabu- } \\
\text { lary }\end{array}$ & $\begin{array}{r}\text { Grammar } \\
\text { structures }\end{array}$ & $\begin{array}{r}\text { Verb } \\
\text { conjug. }\end{array}$ & $\begin{array}{r}\text { Polite } \\
\text { forms }\end{array}$ & $\begin{array}{r}\text { Preposi- } \\
\text { tions }\end{array}$ & Spelling & $\begin{array}{r}\text { Pronun- } \\
\text { ciation }\end{array}$ & None & Total \\
\hline Polish & 1 & 2 & 0 & 0 & 0 & 0 & 1 & 1 & 5 \\
\hline Ukrainian & 0 & 0 & 0 & 0 & 0 & 0 & 0 & 2 & 2 \\
\hline Spanish & 5 & 1 & 1 & 0 & 1 & 1 & 3 & 0 & 12 \\
\hline Kazakh & 0 & 0 & 0 & 0 & 0 & 0 & 0 & 1 & 1 \\
\hline Turkmen & 0 & 0 & 0 & 0 & 0 & 0 & 0 & 1 & 1 \\
\hline Georgian & 0 & 0 & 0 & 0 & 0 & 0 & 0 & 1 & 1 \\
\hline Azerbaijani & 1 & 0 & 0 & 1 & 0 & 0 & 1 & 3 & 6 \\
\hline Albanian & 0 & 0 & 0 & 0 & 0 & 0 & 0 & 1 & 1 \\
\hline Lao & 1 & 1 & 1 & 1 & 1 & 1 & 1 & 0 & 7 \\
\hline
\end{tabular}

Table 7: The similarities perceived by the students between French and their native languages. 
Teaching and learning French as a third or additional language in an international...

The most similarities were perceived by the Spanish speakers, but no Spanish speaker claimed there were no similarities (i.e. none of them marked the answer 'none'). Quite predictably, the most similarities between French and Spanish were observed in vocabulary. No similarities were observed by three Azerbaijani speakers, both Ukrainian speakers, and all the speakers of Kazakh, Turkmen, Georgian and Albanian. Rather surprisingly, the Lao speaker found some similarities, explaining that Laos used to be occupied by the French and a number of borrowings were still in use. However, the chi-square test did not reveal a significant difference between the groups, $(p=0.97, d f=56)$. In other words, apart from the Spanish speakers, most of the students perceive few or no similarities between French and their native languages.

The question whether the similarities made learning French easier or more difficult was answered by only five students: Two Spanish speakers claimed that similarities facilitated understanding and pronunciation, and provided a frame of reference respectively. A Polish speaker noticed the similarity in pronunciation between /õ/ in French and 'ą' in Polish. The Kazakh native speaker wrote that it did not make learning difficult, as the languages were not similar (apparently, she meant less risk of interference), and an Azerbaijani speaker wrote 'not much', which suggests 'not much facilitation'.

By contrast, the differences perceived by the students between French and their native languages are presented in Table 8 below.

\begin{tabular}{|l|r|r|r|r|r|r|r|r|r|}
\hline $\begin{array}{l}\text { Native } \\
\text { language }\end{array}$ & $\begin{array}{r}\text { Vocabu- } \\
\text { lary }\end{array}$ & $\begin{array}{r}\text { strammar } \\
\text { strures }\end{array}$ & $\begin{array}{r}\text { Verb } \\
\text { conjug. }\end{array}$ & $\begin{array}{r}\text { Polite } \\
\text { forms }\end{array}$ & $\begin{array}{r}\text { Preposi- } \\
\text { tions }\end{array}$ & Spelling & $\begin{array}{r}\text { Pronun- } \\
\text { ciation }\end{array}$ & Other & Total \\
\hline Polish & 0 & 1 & 0 & 2 & 1 & 1 & 1 & 1 & 7 \\
\hline Ukrainian & 1 & 2 & 2 & 1 & 1 & 2 & 2 & 0 & 11 \\
\hline Spanish & 0 & 1 & 2 & 1 & 0 & 2 & 3 & 0 & 9 \\
\hline Kazakh & 1 & 1 & 0 & 1 & 1 & 0 & 0 & 0 & 4 \\
\hline Turkmen & 1 & 0 & 1 & 0 & 0 & 1 & 1 & 0 & 4 \\
\hline Georgian & 1 & 1 & 1 & 1 & 1 & 1 & 1 & 0 & 7 \\
\hline Azerbaijani & 4 & 4 & 4 & 1 & 4 & 4 & 3 & 0 & 24 \\
\hline Albanian & 1 & 0 & 0 & 0 & 1 & 0 & 0 & 0 & 2 \\
\hline Lao & 1 & 1 & 1 & 1 & 1 & 1 & 1 & 0 & 7 \\
\hline
\end{tabular}

Table 8: The differences perceived by the students between French and their native languages: a contingency table.

As the results of the chi-square test show, the difference between the groups is not statistically significant, $(p=0.9910, d f=56)$. The students perceived differences in all language areas, especially in pronunciation and spelling, but also in vocabulary, grammar and the use of polite forms. A native Polish speaker also noticed cultural differences resulting in a different logic. 
However, the responses to the question whether the differences facilitated learning or made it more difficult varied considerably. While some students claimed that the differences between French and their native languages (Turkmen, Azerbaijani) made learning French more difficult, the Georgian took a neutral position ('Neither. Since both are very different, they don't affect my studies'), and one Polish and one Ukrainian student found the differences facilitating (the latter wrote he would not combine French and Ukrainian in speech).

As for the perception of similarities and differences between French and other languages, 7 students perceived similarities between French and English, 5- between French and Spanish, 3- between French and Italian, and, one in each case, between French and Russian, Portuguese and German. As for the differences between French and other languages known to the students, 4 students perceived differences between French and English, 3 between French and German and also 3 between French and Russian, 2 between French and Spanish, and, one in each case, between French and Polish, Lao (actually, the student's native language), Korean and Thai. Again, the respondents' attitudes towards similarities and differences vary from the perception of facilitation by similarities (e.g. similarities between English and French make learning French easier for an Azerbaijani speaker, and similarities between Spanish and French make it easier for a Polish speaker, though sometimes she mixes those languages), through the perception of difficulty caused by differences (e.g. the need to learn everything anew) and a more neutral position ('No, it doesn't, I need to learn new ways of thinking in order to learn'), to the admission that the student does not know.

The last part of the questionnaire concerned the students' attitudes towards different aspects of the French language course, feedback and assessment. They were asked to mark on a five-point Likert scale the extent with which they agreed with each statement (see Table 9).

In general, the students like the way the French classes are conducted (mean $=3.71$ ), though, given the high standard deviation, there is considerable divergence. Similarly, they quite appreciate the fact that revision and consolidation activities are based on different textbooks (mean $=3.85, \mathrm{SD}=1.35$ ). As the author believes that activities should be varied to keep students interested, the classes involve reading, listening, dialogues, grammar, pronunciation, cultural information and even games, which largely overlaps with the structure of modern language textbooks. However, as no French language textbook seems to contain everything, the author supplements the main textbook, Alter Ego+, A1 (Hugot et al., 2012), with other materials (see Section 4.2. above). 
Teaching and learning French as a third or additional language in an international...

\begin{tabular}{|l|r|r|}
\hline Statement & Mean & $\begin{array}{r}\text { Standard } \\
\text { deviation }\end{array}$ \\
\hline $\begin{array}{l}\text { I like the way the French classes are conducted because they include dif- } \\
\text { ferent skills (...). }\end{array}$ & 3.71 & 1.31 \\
\hline $\begin{array}{l}\text { I appreciate the feedback from our teacher because it helps me to im- } \\
\text { prove my French. }\end{array}$ & 3.94 & 1.2 \\
\hline I feel that our teacher corrects us too much. & 2.3 & 1.17 \\
\hline We are still beginners, so we need to be corrected. & 4.25 & 0.91 \\
\hline I wish we were not evaluated yet because we are still beginners. & 2.9 & 0.97 \\
\hline I do not like being evaluated at all. & 2.74 & 1.45 \\
\hline $\begin{array}{l}\text { I like it when our teacher makes us aware of similarities and differences } \\
\text { between French and the languages we already know. }\end{array}$ & 3.7 & 1.45 \\
\hline $\begin{array}{l}\text { I appreciate it that our teacher takes a personalized approach and points } \\
\text { out the sources of our errors to us (...). }\end{array}$ & 4.15 & 1.14 \\
\hline $\begin{array}{l}\text { I wish the influence of other languages on our French could be taken } \\
\text { into consideration in the evaluation, but I realise that the tests have to } \\
\text { be the same for everybody and based on the material we have studied. }\end{array}$ & 3.89 & 1.05 \\
\hline Our teacher is fair and we get the grades we deserve. & 4.26 & 1.05 \\
\hline $\begin{array}{l}\text { Learning a foreign language always requires a lot of effort, so we cannot } \\
\text { expect the French course to be easy. }\end{array}$ & 4.35 & 0.75 \\
\hline $\begin{array}{l}\text { I appreciate it that we revise the material and do similar activities from } \\
\text { different textbooks in order to consolidate our knowledge. }\end{array}$ & 3.85 & 1.35 \\
\hline $\begin{array}{l}\text { I like it when we discuss the similarities and differences between French } \\
\text { and other languages. }\end{array}$ & 3.53 & 1.39 \\
\hline $\begin{array}{l}\text { I would rather our teacher spoke only about French and did not talk } \\
\text { about similarities and differences between it and other languages. }\end{array}$ & 2.35 & 1.23 \\
\hline
\end{tabular}

Table 9: The students' attitudes towards the French classes, feedback and assessment.

As for feedback, the students appreciate it (mean = 3.94) and do not think that the teacher corrects them too much (mean $=2.3$ ). They realise that, as beginners, they need to be corrected (mean $=4.25$ ) and they are quite unanimous about it (SD = 0.91). Similarly, they do not agree that they should not yet be evaluated at that level, nor that they do not like evaluation at all. Apparently, they are used to evaluation and regard it as an inherent part of their studies. They realise that the tests have to be the same for all students, regardless of their language backgrounds (mean $=3.89, \mathrm{SD}=1.05$ ). They also generally think that the teacher is fair and gives them the grades they deserve (mean $=4.26, \mathrm{SD}=1.05$ ).

There are bigger differences between the students' attitudes towards pointing out similarities and differences between languages to raise their language awareness, as well as of the sources of their errors (e.g. negative transfer from Spanish into French). They quite like being shown cross-linguistic similarities and differences (mean $=3.7$ ), but their opinions differ, as the standard deviation is very high (1.45). However, this is not the overall tendency, as in response to the statement that they would like the teacher to speak French 
only, the mean was only 2.35 and the standard deviation was slightly lower (1.23). They actually like discussing similarities and differences between languages (mean $=3.53$ ) and they appreciate the teacher's personalised approach, including pointing out the sources of errors (mean $=4.15$ ).

Finally, they realise that learning a foreign language requires a lot of effort, so they cannot expect the French course to be easy (mean $=4.35$ ), and their answers do not vary greatly $(S D=0.75)$. This is also evidence of their language learning experience and language awareness (and also language consciousness, as they realise how much they still have to learn).

\section{Conclusions}

To answer the research questions, first, there are differences in the students' performance depending on their native languages, but these are statistically significant only in the case of vocabulary and semantics, and the multiplechoice task. Even so, in the latter case, the correctness of the answers mostly depends on factors other than language distance. In fact, the influence of the native language on French is not so clear-cut. On the one hand, while similarities generally facilitate learning (cf. Kellerman, 1987) (facilitation which is to some extent noticed by the students), transfer can also be negative, as shown by the native Spanish speakers' errors in French. Moreover, they all know English and some of them know Russian, so even for speakers of very distant languages (Georgian, the Turkic languages, etc.) French is not the first Indo-European language they have ever studied, but while studying English and/or Russian, they developed some appropriate learning strategies. Indeed, the native speaker of Lao wrote that, even though French was difficult for her, English helped her to some extent. Thus, language acquisition by multilinguals is highly complex and, in accordance with the Factor Model (Hufeisen, 2018), the native language is only one of a number of factors, as there are more languages in their linguistic repertoires, different learning experiences, etc.

Second, areas of language that pose the students particular difficulty also differ. As French contains some sounds that are difficult to pronounce, and some grapheme-phoneme mappings are easy to confuse (for example, $/ \mathrm{u} / \mathrm{spelled}$ ' $\mathrm{ou}$ ' and $/ \mathrm{y} / \mathrm{spelled}$ ' $\mathrm{u}$ '), pronunciation is perceived as particularly difficult, as are other skills connected with sound production or recognition (speaking and listening comprehension). As grapheme-phoneme mapping relates to spelling, the students find spelling and writing difficult too. Grammar is also perceived as difficult, except for the Spanish speakers, who can rely on similarities between the Romance languages. 
Third, the students' perception of similarities and differences between French, their L1s and other languages they know generally reflects the actual language areas in which those similarities and differences can be observed. Speakers of Spanish perceive the most similarities, especially in vocabulary, while speakers of more distant languages, such as Albanian, Georgian or the Turkic languages, do not notice any similarities. The areas in which they perceive differences (spelling, pronunciation and to some extent grammar) largely overlap with the areas of difficulty they indicated. However, as to whether this facilitates or inhibits learning, their perceptions vary from a view that similarities and difficulties caused by differences have a facilitative effect, to the opposite view that differences prevent them from mixing languages. Thus, the perception of such effects is largely individual.

Fourth, the students' attitudes towards the French classes are generally positive, albeit varied. They realise the importance of feedback and appreciate it, and they also regard the assessment as fair. With a few exceptions they appreciate the awareness-raising, especially pointing out similarities and differences between languages to them. The exceptions are probably due to those students' language learning experience. In fact, as their levels of language awareness are already high, the students are likely to benefit from awareness-raising activities and exploit that awareness in further learning.

In general, the study confirms earlier observations that multilinguals have higher levels of language awareness. In fact, their positive approach to feedback and evaluation is also a reflection of their language awareness and consciousness (James, 1996). However, the results also reflect a diversity of perceptions, learning experiences, language repertoires, etc., which should be taken into consideration when teaching multilingual students and, if possible, in assessment. The native language is no longer such an important factor as in L2 learning; indeed, another language related to the target language can play a much more important role.

When it comes to the practical applications of this study, first, it provides further evidence that foreign language teaching should help to develop language awareness. However, it is important to make learners aware of the similarities and differences not only between the target language and their native language, but also between the target language and the other languages they know, so that they can use those similarities and differences to organise their knowledge and learn more effectively. The second possible application regards the optimisation of multilingual assessment. Certainly, given such requirements as achieving and documenting achievement of the objectives specified in the syllabus, it is unlikely that teachers will have complete freedom to involve learners' whole multilingual repertoires in the assessment 
of foreign language production. However, a personalised approach, taking into account learners' language repertoires and pointing out the plausible sources of their errors (not only due to negative transfer and interference, but also due to language-specific factors, such as the pronunciation of / $/ \mathrm{k}$ and / $/$ in French) can be helpful and it is actually appreciated by students.

\section{BIBLIOGRAPHY}

Bachman L.F. (2014), Ongoing challenges in language assessment, (in:) Kunnan, A.J. (ed.), The companion to language assessment. Vol. III. Evaluation, methodology and interdisciplinary themes. Hoboken, NJ: John Wiley and Sons, pp. 1-18.

Bialystok E. (1985), The compatibility of teaching and learning strategies. "Applied Linguistics", No 6(3), pp. 255-262.

Byram M. (2012), The Eric Hawkins lecture. Language awareness and (critical) cultural awareness - relationships, comparisons and contrasts. "Language Awareness", No 21, pp. 5-13.

Capelle G., Menand, R. (2009), Le Nouveau Taxi! A1. Paris : Hachette.

De Angelis G. (2007), Third or additional language acquisition. Clevedon/Buffalo/Toronto: Multilingual Matters Ltd.

Edelenbos P., Kubanek-German A. (2004), Teacher assessment: the concept of 'diagnostic competence'. "Language Testing", No 21(3), pp. 259-283.

Gorter D., Cenoz J. (2017), Language education policy and multilingual assessment. "Language and Education", No 31(3), pp. 231-248.

Grégoire M., with the participation of Merlo, G. (2010), Grammaire progressive du français. Niveau débutant. Paris: CLE International.

Herdina P., Jessner U. (2002), A dynamic model of multilingualism. Perspectives of change in psycholinguistics. Clevedon: Multilingual Matters Ltd.

Hill K., McNamara T. (2012), Developing a comprehensive, empirically-based research framework for classroom-based assessment. "Language Testing", No 29(3), pp. 395-420.

Hufeisen B. (2018), Models of multilingual competence, (in:) Bonnet, A., Siemund, P. (eds.), Foreign language education in multilingual classrooms. Amsterdam/Philadelphia: John Benjamins Publishing Company, pp. 173-189.

Hugot C. et al. (2012), Alter Ego+, A1. Méthode de français. Paris: Hachette.

James C. (1996), A cross-linguistic approach to language awareness. "Language Awareness", No 5, pp. 138-148.

Jessner U. (1999), Metalinguistic awareness in multilinguals: cognitive aspects of third language learning. "Language Awareness", No 8, pp. 201-209. 
Kellerman E. (1987), Aspects of Transferability in Second Language Acquisition. Nijmegen: Katholieke Universiteit Nijmegen.

Klein E.C. (1995), Second versus third language acquisition: Is there a difference? "Language Learning", No 45(3), pp. 419-465.

Müller-Lancé J. (2003), Der Wortschatz romanischer Sprachen im Tertiärsprachenerwerb.Lernerstrategien am Beispiel des Spanischen, Italienischen und Katalanischen. Tübingen: Stauffenburg Verlag.

Rea-Dickins P. (2007), Classroom-based assessment: Possibilities and pitfalls, (in:) Cummins, J., Davidson, C. (eds.), International handbook of English language teaching. Boston, MA: Springer, pp. 505-520.

Singleton D. (2000), Language and the lexicon. An introduction. London: Arnold. Velupillai V. (2012), An introduction to linguistic typology. Amsterdam/Philadelphia: John Benjamins Publishing Company.

Włosowicz T.M. (2009), Transfer and the construction of multilingual competence: the perception and use of similarities between Swedish, German and English by Polish learners of Swedish as L4. Paper presented at the 21st International Conference on Foreign/ Second Language Acquisition, Szczyrk, 28-30.05.2009.

Włosowicz T.M. (2016), Adult learners' expectations concerning foreign language teachers and the teaching-learning process, (in:) Gabryś-Barker, D., Gałajda, D. (eds.), Positive Psychology Perspectives on Foreign Language Learning and Teaching. Springer International Publishing Switzerland, pp. 267-285.

Wlosowicz T.M. (2017), Les recherches sur le plurilinguisme en tant que défi pour la linguistique appliquée. "Synergies Brésil", No 12, pp. 119-132. 


\section{Appendix 1:}

Selected items from the tasks included in the French language tests.

Selected items from a gap-filling task for the sixty-hour group:

1. Avez-vous le dernier roman d'Amélie Nothomb en livre de $p$ ?

2. 'Buvez-vous du café? - 'Oui, j' bois.'

3. Pour ma salade, je voudrais deux $\mathrm{p}$ verts, un oignon et trois tomates.

4. Combien c un pot de crème fraîche?

Selected items from a gap-filling task for the thirty-hour group:

1. Bonjour, Natacha, ça fait

2. Marina habite Moscou, de te voir!

3. "Quelle est votre Russie.

5. Ils s' Kaj et Elsa. Ils habitent Danemark.

Selected items from an error correction task for the sixty-hour group:

1. «Avez-vous des pommes de terre? »

"Oui, madame. »

" Je voudrais trois kilos. "

2. "C'est ta sœur ? » - « Non, c'est je ! »

3. Le saumon est un légume.

Completing a dialogue for the sixty-hour group (an excerpt):

Cliente: Bonjour.

Vendeuse: Bonjour. Vous ?

Cliente: Je Vendeuse: Voilà. Et avec ça ? un kilo de pommes et deux bananes.

Cliente: -vous des poires?

Vendeuse: Oui, elles sont là, à

Cliente: Alors, une de poires, s'il vous . (..)

Selected items from the multiple-choice task for the sixty-hour group:

1. 'Bois-tu du vin?' 'Non, je bois pas.'
a) ne b) du c) n'en d) ne le

2. 'Et avec ceci, madame ?' 'Je vais aussi une botte de radis et une livre de cerises.'
a) prendre b) désirer c) manger d) payer

3. Je vous combien?
a) fais b) dis c) dois
d) coûte

4. Je voudrais une de jambon.

a) bouteille b) botte c) barquette d) tranche

5. Les bananes ne sont pas encore

a) mûres b) vertes $c$ ) rouges $d$ ) fraîches 
Appendix 2:

The questionnaire used in the study

Sex: $\mathrm{F}$

1) L1 (native language):

L2: Level of proficiency:

L3: Level of proficiency:

What other languages have you studied? (Please, indicate your proficiency levels.)

2) How difficult do you find French? (1 - very easy, 5 - very difficult) 12345

a) Which aspects of French do you find particularly difficult? (You can mark as many answers as you find relevant.)

$\square$ grammar

$\square$ vocabulary

$\square$ spelling

$\square$ pronunciation

$\square$ speaking

$\square$ writing

$\square$ reading comprehension

$\square$ listening comprehension

$\square$ something else (please, specify)

b) Do you perceive any similarities between French and your native language? Yes/ No

If you do, what areas do you perceive those similarities in? (You can mark as many answers as you find relevant.)

$\square$ vocabulary

$\square$ grammatical structures

$\square$ verb conjugation

$\square$ polite forms

$\square$ the use of prepositions

$\square$ spelling

$\square$ pronunciation

$\square$ something else (please, specify)

Do the similarities between French and your native language facilitate your learning of French, or do they make it more difficult? Please, justify your answer.

c) In what language areas do you perceive differences between French and your native language? (You can mark as many answers as you find relevant.)

$\square$ vocabulary

$\square$ grammatical structures

$\square$ verb conjugation

$\square$ polite forms 
$\square$ the use of prepositions

$\square$ spelling

$\square$ pronunciation

$\square$ something else (please, specify)

Do the differences between French and your native language facilitate your learning of French, or do they make it more difficult? Please, justify your answer.

d) Do you perceive any similarities between French and another language you already know (please, specify the language(s): ) ? Yes/ No

If you do, what areas do you perceive those similarities in? (You can mark as many answers as you find relevant.)

$\square$ vocabulary

$\square$ grammatical structures

$\square$ verb conjugation

$\square$ polite forms

$\square$ the use of prepositions

$\square$ spelling

$\square$ pronunciation

$\square$ something else (please, specify)

Do the similarities between French and the language(s) you already know facilitate your learning of French, or do they make it more difficult? Please, justify your answer.

In what language areas do you perceive differences between French and another language you already know (please, specify the language(s): )? (You can mark as many answers as you find relevant.)

$\square$ vocabulary

$\square$ grammatical structures

$\square$ verb conjugation

$\square$ polite forms

$\square$ the use of prepositions

$\square$ spelling

$\square$ pronunciation

$\square$ something else (please, specify)

Do the differences between French and the language(s) you already know facilitate your learning of French, or do they make it more difficult? Please, justify your answer.

3) To what extent do you agree with the following statements? (1 - completely disagree, 5 - fully agree) 
I like the way the French classes are conducted because they include different skills (grammar, vocabulary, listening comprehension, cultural information, etc.).

12345

I appreciate the feedback from our teacher because it helps me to improve my French.

12345

I feel that our teacher corrects us too much.

12345

We are still beginners, so we need to be corrected.

12345

I wish we were not evaluated yet because we are still beginners. 12345

I do not like being evaluated at all.

12345

I like it when our teacher makes us aware of similarities and differences between French and the languages we already know.

12345

I appreciate it that our teacher takes a personalized approach and points out the sources of our errors to us (e.g. the influence of Spanish or Russian on our French).

12345

I wish the influence of other languages on our French could be taken into consideration in the evaluation, but I realise that the tests have to be the same for everybody and based on the material we have studied. 12345

Our teacher is fair and we get the grades we deserve.

12345

Learning a foreign language always requires a lot of effort, so we cannot expect the French course to be easy.

12345

I appreciate it that we revise the material and do similar activities from different textbooks in order to consolidate our knowledge.

12345

I like it when we discuss the similarities and differences between French and other languages.

12345

I would rather our teacher spoke only about French and did not talk about similarities and differences between it and other languages.

12345

Would you like to add a comment of your own?

Thank you very much. :; 